\title{
Chemopreventive Potential of Canola Leafy Greens and Other Cruciferous Vegetables on Azoxymethane (AOM)-Induced Colon Cancer in Fisher-344 Male Rats
}

\author{
R. L. Miller-Cebert ${ }^{1}$, J. Boateng1 ${ }^{1}$ E. Cebert ${ }^{2}$, L. Shackelford ${ }^{1}$, M. Verghese ${ }^{1 *}$ \\ ${ }^{1}$ Nutritional Biochemistry and Carcinogenesis Laboratory, Department of Food and Animal Sciences, Alabama A\&M University, Normal, \\ AL, USA \\ ${ }^{2}$ Department of Biological and Environmental Sciences, Alabama A\&M University, Normal, AL, USA \\ Email: *martha.verghese@aamu.edu
}

How to cite this paper: Miller-Cebert, R.L., Boateng, J., Cebert, E., Shackelford, L. and Verghese, M. (2016) Chemopreventive Potential of Canola Leafy Greens and Other Cruciferous Vegetables on Azoxymethane (AOM)-Induced Colon Cancer in Fisher-344 Male Rats. Food and Nutrition Sciences, 7, 964-976.

http://dx.doi.org/10.4236/fns.2016.711095

Received: August 10, 2016

Accepted: September 19, 2016

Published: September 22, 2016

Copyright $\odot 2016$ by authors and Scientific Research Publishing Inc. This work is licensed under the Creative Commons Attribution International License (CC BY 4.0).

http://creativecommons.org/licenses/by/4.0/ (c) (i) Open Access

\begin{abstract}
Cruciferous vegetables have great health benefits, and their components may be significant in the inhibition of colon tumors. The objective of this study was to investigate and compare the chemopreventive potential of cabbage, turnip greens, collard greens and canola greens on azoxymethane (AOM)-induced colon cancer. Following a one-week acclimatization period, forty-two Fisher-344 male rats were randomly assigned to five groups (treatment groups: $\mathrm{n}=8$; control: $\mathrm{n}=10$ ). Four groups were fed treatment diets consisting of the selected cruciferous vegetables at $5 \%$, while the $\mathrm{C}$ group was fed AIN-93 growth diet. Colon tumors were induced by administration of $\mathrm{AOM}$ at 7 and 8 weeks of age and rats were killed by $\mathrm{CO}_{2}$ asphyxiation at 45 weeks of age. Results show a $42.85 \%$ tumors incidence in rats fed canola greens compared to $100 \%$ in the rats fed cabbage and the control. Rats fed control had higher tumors/ tumor bearing rat (TBR) ratio (4.5) compared to those seen in treatment groups (1 1.71). Significant differences ( $\mathrm{P} \leq 0.05$ ) were noted in weight gain, cecal wall weight and total cecal weight in the control compared to treatment groups. Hepatic catalase (CAT) and Glutathione-S-Transferase (GST) activities (43.05 and $2.02 \mu \mathrm{mol} / \mathrm{mg}$, respectively) in rats fed canola were significantly higher $(\mathrm{P} \leq 0.05)$ compared to the control $(10.22$ and $0.58 \mu \mathrm{mol} / \mathrm{mg}$ ) and other treatment groups. Superoxide dismutase (SOD) activity $(\mu \mathrm{mol} / \mathrm{mg})$ in rats fed canola $(0.29)$, cabbage $(0.26)$ and turnip greens $(0.25)$ were similar, however, significantly higher $(\mathrm{P} \leq 0.05)$ compared to the control (0.09). Activities of glutathione peroxidase (GPX) increased in the order: collard greens $>$ canola greens $>$ turnip greens $>$ cabbage $>$ control. Selected cruciferous vegetables, including canola leafy greens, were effective in reducing incidence of AOM-
\end{abstract}


induced colon tumors in Fisher-344 male rats and may be useful as dietary chemopreventive agents.

\section{Keywords}

Antioxidative Enzymes, Cancer, Canola, Cruciferous Vegetables, Detoxification Enzymes

\section{Introduction}

Lifestyle diseases such as cancer, obesity, and diabetes are among the primary cause of mortality in many industrialized nations, accounting for millions of deaths yearly [1]. Cancer, the second leading cause of deaths in the United States, remains one of the greatest challenges to the public health system [2] with pronounced economic impact. In the United States, colorectal cancer is ranked the third most commonly diagnosed cancer and the third leading cause of cancer deaths in humans [3].

It has been established that diet and lifestyle play an important preventive role in cancer, accounting for a 30\%-40\% tumor reduction [2]. Oxidative damage, which occurs from excess reactive oxygen species (ROS) in cells, is a major cause of diseases in humans, and as such, foods that are rich sources of antioxidants play an integral role in reducing the incidence of cancer and other chronic diseases [4].

Vegetables are among the many studied foods that offer health protective properties with varying mechanism [2]. In particular, vegetables of the cruciferous family have been evaluated for their nutritional and phytochemical benefits as they relate to chemoprevention [5]-[7]. Cruciferous vegetables such as turnip greens (Brassica campestris var. rapifera), cabbage (Brassica oleraceae L. var. capitata) and collard greens (Brassica oleraceae var. viridis), provide numerous nutrients that work synergistically to prevent cancer [8]. Canola (Brassica napus), a member of the family of cruciferous vegetables, is a highly desirable oilseed commodity crop. However, there has been limited research on the utilization of canola's biomass as a green leafy vegetable. Miller-Cebert et al. [9] in their study of nutrients composition in canola leafy greens, suggest that canola greens may be as nutritious as other cruciferous vegetables such as collard greens, kale and cabbage.

The objective of this study was to evaluate the chemopreventive potential of selected cruciferous vegetables (canola greens, cabbage, turnip greens and collard greens) in reducing colon cancer in Fisher-344 male rats.

\section{Materials and Methods}

\subsection{Chemicals}

Azoxymethane (AOM) was obtained from Midwestern Research Institute, NCI, Chemical Repository, Kansas City, MO, USA. All other chemicals and reagents were of analytical grade and were purchased from Sigma Chemical Company, St Louis, MO. 


\subsection{Cruciferous Vegetables}

Collard greens, cabbage and turnip greens were obtained from a local health-food store. Canola was obtained from the Winfred Thomas Agricultural Research Station (Alabama A\&M University). All leafy vegetable samples were washed in deionized water, and stored in a $-80^{\circ} \mathrm{C}$ freezer. Frozen samples were later transferred from $-80^{\circ} \mathrm{C}$ to a Consul 24 Virtis freeze-dryer (The Virtis Company, Gardiner, NY). The freeze-dried samples were milled using a Robot Coupe, Blixer RS1 BX3 Food Processor (Robot Coupe U.S.A. Inc. Ridgeland, MS).

\subsection{Animal Housing and Diet}

Fisher-344 male rats were obtained from Harlan, IN and housed in stainless steel cages. Following one week of acclimatization, the rats were randomly assigned to five groups; eight rats in each treatment group and ten rats in the $\mathrm{C}$ group. The rats were fed AIN (American Institute of Nutrition) 93G C growth diet [10] [11], canola greens, collard greens, cabbage, and turnip greens at $5 \%$. Temperature and relative humidity were maintained at $21^{\circ} \mathrm{C}$ and $50 \%$ respectively, with 12-hour light and dark cycles. Biweekly body weights and feed intakes were recorded throughout the experimental period.

\subsection{Carcinogen Injection and Sample Preparation}

All animals received two subcutaneous injections of AOM (NCI Repository, Kansas, MO) at 7 and 8 weeks of age, at $16 \mathrm{mg} / \mathrm{kg}$ body weight. Rats were killed by $\mathrm{CO}_{2}$ asphyxiation at 45 weeks of age. Liver samples were collected and stored at $-80^{\circ} \mathrm{C}$ for enzyme analysis. Cecum was removed; cecal contents and weight of cecal wall were determined.

\subsection{Characteristics of Colon Tumors}

For the characterization of tumor size, tumor location and tumor per tumor bearing rat ratio (TBR), the protocol of Shackelford and others was employed [12].

\subsection{Detoxification Enzyme Analysis}

Hepatic Glutathione S Transferase (GST) was determined following the manufacturer's protocol (Cayman Chemical Company). GST activity was measured at an absorbance of $340 \mathrm{~nm}$ using a microplate reader (Biotek Synergy HT, Winooski, Vermont).

\subsection{Antioxidant Enzyme Analysis}

Glutathione (GSH), Glutathione Peroxidase (GPX) and Superoxide Dismutase (SOD) were determined using a microplate reader (BioTek Synergy HT Winooski, Vermont) as described in the manufacturer's protocol (Cayman Chemicals, Ann Arbor, MI). Change in absorbance was monitored at $412,340,460 \mathrm{~nm}$, respectively. Catalase (CAT) activity was determined using an established protocol as described by Johansson and Borg (1988) [13]. Quantification was carried out by measuring the absorbance at 540 $\mathrm{nm}$ using a microplate reader (Biotek Synergy HT, Winooski, Vermont) and catalase activity was compared with those obtained from formaldehyde standards. 


\subsection{Statistical Analysis}

Data were analyzed using the SAS system version 9.1 (SAS Institute, Cary, NC). Values are given as means \pm SEM and were separated using Duncan's Multiple Range Test, with significance at $\mathrm{P} \leq 0.05$ level.

\section{Results}

\subsection{Effects of Cruciferous Vegetables on Feed Intake, Body Weight, Cecal Weight and Cecal pH}

Feed intake in rats fed canola greens was significantly $(\mathrm{P} \leq 0.05)$ lower $(13.26 \mathrm{~g} /$ week $)$ compared to the rats fed collard greens ( $14.78 \mathrm{~g} /$ week). The group fed the control diet had a significantly higher $(\mathrm{P} \leq 0.05)$ feed intake $(16.80 \mathrm{~g} / \mathrm{week})$ compared to the rats fed the selected vegetables (Table 1). There were no significant differences among the treatment groups in terms of body weight, total cecal weight and cecal $\mathrm{pH}$. Highest weight gain (g/41 week) was seen in rats fed collard greens (258.75), while the lowest weight gain was observed in the animals that were fed the control (222.62). No significant differences were observed in cecal weight $(\mathrm{g})$ among the rats fed the selected vegetables, but significantly lower $(P \leq 0.05)$ cecal weight was noted in the control group compared to the treatment groups. Cecal weight ranged from a low of 1.26 in canola greens to 3.13 in turnip greens.

Ingestion of the selected cruciferous vegetables affected cecal wall weight ( $g$ ) in the rats used in this study. As shown in Table 1, the control group had significantly ( $\mathrm{P} \leq$ 0.05) lower cecal wall weight (0.48) compared to the treatment groups. Comparing the treatment groups, cecal wall weight was significantly $(P \leq 0.05)$ higher in the rats fed the turnip greens diet compared to cabbage and canola greens diets at 1.18 and 1.21 respectively, but were not significantly different from the rats fed the collard greens diet (1.37). Though no significant differences were observed among all the groups, cecal $\mathrm{pH}$ ranged from a low of 7.59 in rats fed the canola greens diet to a high of 7.99 in the

Table 1. Effect of cruciferous vegetables on feed intake, total cecal weight, cecal wall weight and cecal pH.

\begin{tabular}{cccccc}
\hline Groups & $\begin{array}{c}\text { Feed intake } \\
(\mathrm{g} / \text { week })\end{array}$ & $\begin{array}{c}\text { Weight } \\
\text { gain }(\mathrm{g} / 41 \\
\text { week })\end{array}$ & $\begin{array}{c}\text { Total cecal } \\
\text { weight }(\mathrm{g})\end{array}$ & $\begin{array}{c}\text { Cecal wall } \\
\text { Weight }(\mathrm{g})\end{array}$ & Cecal pH \\
\hline Control & $16.80^{\mathrm{a}} \pm 1.66$ & $222.62^{\mathrm{b}} \pm 5.20$ & $1.26^{\mathrm{b}} \pm 0.04$ & $0.48^{\mathrm{b}} \pm 0.02$ & $7.99^{\mathrm{a}} \pm 0.08$ \\
Cabbage & $14.58^{\mathrm{bc}} \pm 2.88$ & $256.25^{\mathrm{a}} \pm 6.87$ & $2.88^{\mathrm{a}} \pm 0.12$ & $1.18^{\mathrm{b}} \pm 0.12$ & $7.64^{\mathrm{a}} \pm 0.07$ \\
$\begin{array}{l}\text { Turnip } \\
\text { greens }\end{array}$ & $13.64^{\mathrm{bc}} \pm 1.16$ & $248.87^{\mathrm{a}} \pm 6.80$ & $3.13^{\mathrm{a}} \pm 0.12$ & $1.47^{\mathrm{a}} \pm 0.07$ & $7.60^{\mathrm{a}} \pm 0.06$ \\
$\begin{array}{l}\text { Collard } \\
\text { greens }\end{array}$ & $14.78^{\mathrm{b}} \pm 2.78$ & $258.75^{\mathrm{a}} \pm 7.58$ & $3.08^{\mathrm{a}} \pm 0.18$ & $1.37^{\mathrm{ab}} \pm 0.07$ & $7.65^{\mathrm{a}} \pm 0.9$ \\
$\begin{array}{l}\text { Canola } \\
\text { greens }\end{array}$ & $13.26^{\mathrm{c}} \pm 3.72$ & $246.28^{\mathrm{a}} \pm 0.123$ & $2.86^{\mathrm{a}} \pm 0.18$ & $1.21^{\mathrm{b}} \pm 0.08$ & $7.59^{\mathrm{a}} \pm 0.15$ \\
\hline
\end{tabular}

Values are means \pm SEM. ${ }^{\text {abc }}$ Means in a column with the same superscript do not significantly differ $(\mathrm{P} \leq 0.05)$ using Duncan Multiple Range Test. 
group fed the control diet.

\subsection{Effects of Selected Cruciferous Vegetables on Colonic Tumor Number and Size in Fisher-344 Male Rats}

The highest number of tumors was observed in the rats fed the control diet compared to the rats fed the treatment diets. Tumor numbers in rats fed the control diet were higher in both distal (15) and proximal (30) colon compared to the treatment diets (Table 2). Among the treatment groups, total tumor numbers ranged from a low of 3 in the rats fed canola greens to a high of 12 in those fed cabbage and collard green diets. With the exception of the rats that were fed the collard greens diet, higher number of tumors was seen in the distal portion of the colon compared to the proximal. Among the treatment groups, the smallest tumors $(\mathrm{mm})$ were observed in rats fed collard greens diet (1.45) compared to those fed canola greens diet (4.33). This represents approximately $80 \%$ smaller tumors compared to the control, while the rats fed cabbage and canola greens had tumors that were at least $40 \%$ smaller than the rats fed the control diet.

\subsection{Tumor Incidence and Tumor/Tumor Bearing Rat Ratio (TBR)}

Tumor incidence was highest in the rats fed the control and cabbage diets, compared to the other groups (Table 2). With the exception of the group fed the cabbage diet, tumor incidence was higher in the distal colon compared to the proximal colon. Rats fed the canola greens diet, had lower tumor incidence (42.85\%) compared to their counterparts. Tumors per tumor bearing rat ratio (TBR) is the ratio of the number of tumors seen in rats with tumors [14]. TBR is used in endpoint animal model studies, because it is a suitable tool for studying the effects of different phytochemicals in various foods, and their ability to inhibit tumor development [15]. Among the treatment groups, TBR ranged from 1 in the group fed canola greens diet to 1.71 in the group fed the collard greens diet. Although the rats fed the collard greens diet had a lower tumor incidence (87.5\%) compared to the group fed the cabbage diet (100\%), TBR was higher in the rats fed the collard greens diet (1.71) compared to rats fed the cabbage (1.5) diet.

\subsection{Antioxidative Enzyme Activities in Liver of Fisher-344 Male Rats}

Table 3 shows selected enzyme activities in rats fed the control, canola greens, collard

Table 2. Tumor number, size, location, tumor incidence and tumor/tumor bearing rat (TBR) in the colon of Fisher-344 male rats.

\begin{tabular}{|c|c|c|c|c|c|c|c|c|}
\hline Groups & $\begin{array}{c}\text { Number of } \\
\text { rats }\end{array}$ & $\begin{array}{c}\text { Rats with } \\
\text { tumors }\end{array}$ & $\begin{array}{c}\text { Number of } \\
\text { tumors }\end{array}$ & $\begin{array}{c}\text { Size of } \\
\text { Tumors }(\mathrm{mm})\end{array}$ & $\begin{array}{c}\text { Tumors/tumor } \\
\text { bearing rats }\end{array}$ & $\begin{array}{c}\text { Tumor } \\
\text { incidence\% }\end{array}$ & \multicolumn{2}{|c|}{$\begin{array}{c}\text { Location } \\
\text { proximal distal }\end{array}$} \\
\hline Control & 10 & 10 & 45 & 7.46 & 4.5 & 100 & 15 & 30 \\
\hline Turnip greens & 8 & 6 & 8 & 2.25 & 1.33 & 75 & 3 & 5 \\
\hline Collard greens & 8 & 7 & 12 & 1.45 & 1.71 & 87.5 & 8 & 4 \\
\hline
\end{tabular}


Table 3. Effects of feeding cruciferous vegetables on antioxidative enzymes Catalase (CAT), Superoxide Dismutase (SOD), Glutathione Peroxidase (GPX) activities ( $\mu \mathrm{mol} / \mathrm{mg}$ ) in Fisher-344 male rats.

\begin{tabular}{ccccc}
\hline Groups & SOD & CAT & GPX & GSH \\
\hline Control & $0.09^{\mathrm{c}} \pm 0.02$ & $10.22^{\mathrm{d}} \pm 0.68$ & $0.32^{\mathrm{c}} \pm 0.15$ & $54.16^{\mathrm{c}} \pm 2.98$ \\
Cabbage & $0.26^{\mathrm{b}} \pm 0.08$ & $27.51^{\mathrm{b}} \pm 1.47$ & $3.00^{\mathrm{b}} \pm 0.59$ & $203.90^{\mathrm{b}} \pm 10.98$ \\
Turnip greens & $0.25^{\mathrm{b}} \pm 0.00$ & $14.79^{\mathrm{c}} \pm 1.49$ & $3.59^{\mathrm{ab}} \pm 0.33$ & $236.07^{\mathrm{a}} \pm 10.20$ \\
Collard greens & $1.71^{\mathrm{a}} \pm 0.25$ & $27.58^{\mathrm{b}} \pm 2.17$ & $4.38^{\mathrm{a}} \pm 0.24$ & $221.66^{\mathrm{ab}} \pm 7.60$ \\
Canola greens & $0.29^{\mathrm{b}} \pm 0.07$ & $43.05^{\mathrm{a}} \pm 2.81$ & $4.24^{\mathrm{a}} \pm 0.57$ & $217.22^{\mathrm{ab}} \pm 7.15$ \\
\hline
\end{tabular}

Values are means \pm SEM. abcd Means in a column with the same superscript do not significantly differ $(\mathrm{P} \leq 0.05)$ using Duncan Multiple Range Test.

greens, turnip greens and cabbage diets. Significantly lower $(\mathrm{P} \leq 0.05)$ superoxide dismutase activity (SOD) $(\mu \mathrm{mol} / \mathrm{mg})$ was observed in the control fed rats (0.09) compared to the treatment groups. Among the treatment groups, SOD activity was higher in the rats fed collard greens, showing a significantly higher $(\mathrm{P} \leq 0.05)$ activity $(1.71)$ compared to the canola greens (0.29), cabbage (0.26), and turnip greens (0.25) fed rats. No significant differences were observed in SOD activity among rats fed canola greens, cabbage and turnip greens.

Hepatic catalase (CAT) activity $(\mu \mathrm{mol} / \mathrm{mg})$ in rats fed the control diet was significantly lower $(\mathrm{P} \leq 0.05)$ compared to the treatment groups, and ranged from a low of 10.22 in the control to a high of 43.05 in rats fed canola greens. A $31 \%$ to $76 \%$ higher catalase activity was noted in rats fed the treatment diets compared to the control. All groups showed significantly $(\mathrm{P} \leq 0.05)$ different CAT activity with the exception of cabbage (27.51) and collard greens (27.58) fed group where no significant differences were observed.

Glutathione peroxidase (GPX) activity in rats fed cabbage (3.0) was significantly ( $\mathrm{P} \leq$ 0.05) lower compared to activities in groups fed collard (4.38) and canola greens (4.24). However, all treatment groups had significantly $(\mathrm{P} \leq 0.05)$ higher GPX activity compared to the control (0.32). Glutathione (GSH) levels ( $\mu \mathrm{mol} / \mathrm{mg}$ ), ranged from 203.90 (cabbage) to 236.07 (turnip greens) in rats fed the treatment diets. GSH levels in the rats fed the treatment diets were at least three fold higher compared to the levels observed in the rats fed the control diet (54.16).

\subsection{Detoxification Enzyme Activity}

Hepatic Glutathione S Transferase (GST) activity $(\mu \mathrm{mol} / \mathrm{mg})$ in rats fed treatment diets was significantly $(\mathrm{P} \leq 0.05)$ higher compared to the control (Figure 1$)$. Among the treatment groups, rats fed canola greens had the highest GST activity (2.02) while the lowest activity was seen in the group fed the cabbage (1.39) diet. There were no significant differences seen in GST activity between rats fed turnip greens and collard greens. GST activity in rats fed treatment diets was three to four fold higher compared to the control. 


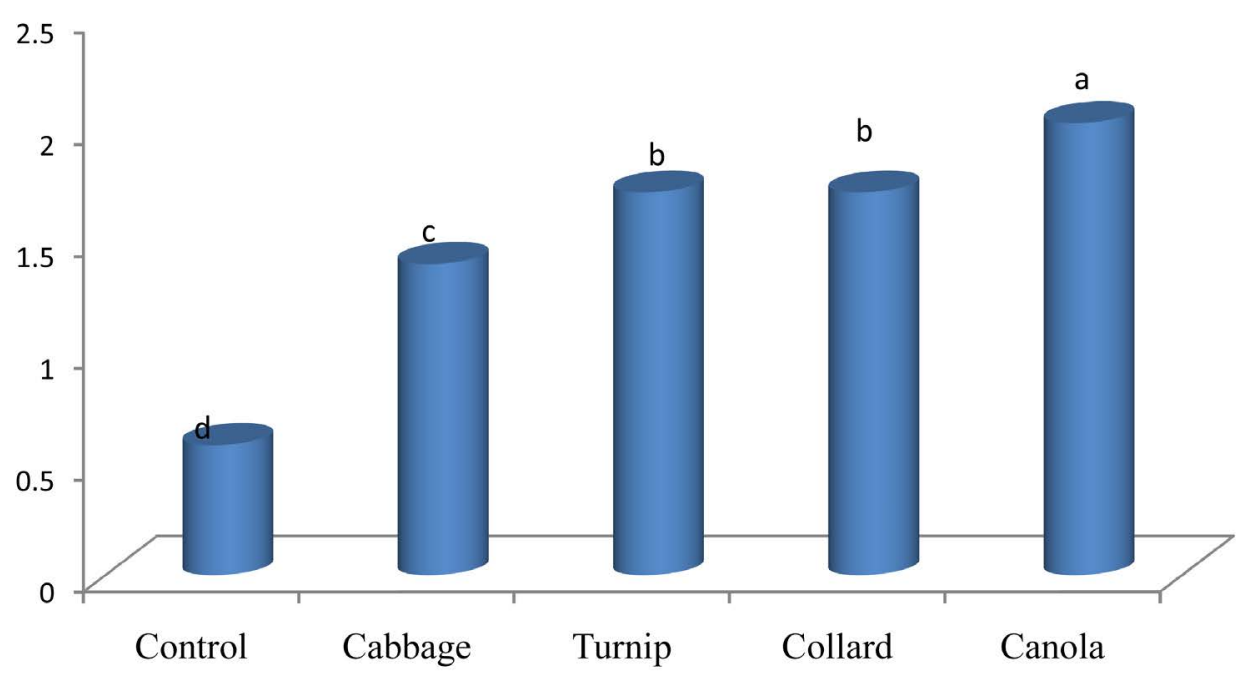

Figure 1. Effects of feeding diets containing cabbage, turnip green, collard green and canola greens on Hepatic Glutathione S Transferase $(\mu \mathrm{mol} / \mathrm{mg})$ in Fisher-344 male rats. ${ }^{\text {abcd }}$ Bars with the same letter do not significantly differ $(\mathrm{P} \leq 0.05)$ using Duncan Multiple Range test.

\section{Discussion}

Epidemiological studies and clinical trials support the notion that natural plant compounds such as isothiocyanates and indole-3-carbinol found in cruciferous vegetables may provide protective effects both in vivo and in vitro carcinogenic models [6] [8] [16]. Isothiocyanates, nitriles and thiocyanates, the three major breakdown products from the hydrolysis of glucosinolates are bioactive agents that upregulate detoxification enzymes [17]. Similar to other monofunctional inducers, isothiocyanates stimulate transcription of phase 2 enzymes by acting on an AP-1-like enhancer element present in certain GST genes [18]. Not only do these bioactive compounds act as monofunctional inducers by regulating phase II detoxification enzymes such as GST, but they may also be capable of biofunctional properties, thereby inducing phase 1 enzymes such as Cytochrome P1A1 [7]. The former, however is the most associated mechanism of action for the reduction seen in numerous cancer studies using cruciferous vegetables. This study was designed to evaluate and compare the effects of canola leafy greens and traditional cruciferous vegetables in preventing colon carcinogenesis.

The results of this study indicate that rats fed the control diet had significantly ( $\mathrm{P} \leq$ 0.05) lower weight gain (g/41 week) compared to the treatment diets (Table 1). The higher weight gain seen in rats fed the cruciferous vegetable diets compared to the control may be a result of the production of short chain fatty acids (SCFA) which occurs during the fermentation of fiber and may translate into a decrease in tumor burden. Tumor burden, which refers to the size of tumors, is an independent prognostic factor that can predict a disease state in certain cancers [19]. A marked increase in the size of the tumors in the rats fed the control diet compared to those fed the treatment diets was observed. One effect of increased tumor burden in a subject is its ability to cause profound alteration in metabolism, thereby preventing the absorption of nutrients. The metabolic alterations that accompany malignancies affect macromolecules, such as 
carbohydrates, proteins and lipids [20]. It has been documented that the colonocytes utilize SCFAs, butyrate, acetate and propionate as metabolic fuels, with butyrate possibly responsible for over $70 \%$ of oxygen consumed by tissues [21]. Wong and colleagues [22] proposed that, unlike butyrate which functions primarily in the colon, acetate enters the peripheral circulation to be metabolized, while propionate is taken up by the liver.

Although no significant differences $(\mathrm{P} \leq 0.05)$ were observed among the treatment groups, rats fed canola greens had the lowest weight gain. Studies have shown that a lower weight gain can decrease the carcinogenic response [23]. Previous study indicate that in most cancer studies using animal models, the lowest weight gain is often found in animals with the lowest tumor numbers [24]. This is consistent with the results seen in the treatment groups used in this study, with rats fed canola leafy greens having the lowest weight gain and tumor numbers compared to the rats fed other green leafy vegetable.

While no significant differences in cecal weight were observed among the treatment groups, significantly $(\mathrm{P} \leq 0.05)$ lower cecal weight was observed in the control group. A study by Sakata suggests that SCFA has the potential to accelerate cell proliferation resulting in an increase in cecal tissue weight [25]. The increase in cecal weight and cecal wall weight, as purported by Campbell, Fahey, and Wolf, may be due to the presence of soluble dietary fiber in the treatment diets which causes fermentation, thus providing butyrate as an energy source and ultimately increasing crypt depth and cell density [26].

The lower $\mathrm{pH}$ observed in the treatment groups compared to the control is likely the result of soluble fiber which is naturally present in cruciferous vegetables. Studies have shown that dietary fiber alters the colonic microflora, thereby decreasing the growth of pathogenic bacteria, creating an anti-carcinogenic environment [27], which is normally associated with lower $\mathrm{pH}$. In addition, butyrate which has been studied for its role in nourishing the colonic microflora, may decrease the transformation of primary bile acids to secondary bile acids as a result of colonic acidification [22] [28]. Research has shown that butyrate inhibits colonic tumors by promoting apoptosis, differentiation and cell cycle arrest of transformed colonocytes [29] [30]. The apoptosis-inducing property of compounds such as ITCs present in cruciferous vegetables is one proposed mechanism by which these vegetables offer chemopreventive protection in animal models [31].

Findings in this study indicate a reduction in tumor number, tumor size, tumor incidence and tumor/tumor-bearing rat in the treatment groups compared to the control. The presence of tumors of varying sizes may be dependent on the tumors' blood vessel supply [32]. The lower number of tumors in the treatment groups may be due to the inhibition of angiogenesis by the presence of compounds present in cruciferous vegetables. Another possible mechanism for the reduction of tumors may be the flavonoids and other phenolic compounds in Brassica vegetables which have antioxidant and free radical scavenging potentials [33]. Some studies propose that an increase in tumor incidence is associated with inflammation [34] [35]. Plant foods possess phytochemical 
compounds which are inhibitors of cyclo-oxygenase (COX) [36] [37]. Sulforaphane which is abundant in cruciferous vegetables, may act as an anti-inflammatory agent [38], thereby inhibiting the activation of nuclear factor Kappa B (NF- $\kappa \mathrm{B}$ ) and COX-2 which are both implicated in inflammatory diseases such as cancer [39] [40]. Among the vegetables tested in this study, a noticeable decrease in tumor incidence and tumor number was observed in the rats fed the canola greens diet. Research by Barrett and colleagues demonstrated that feeding rats with canola seed meal resulted in a lower tumor incidence compared to rats fed a soybean meal diet [41]. The authors implicated the effects seen in canola meal to the level of glucosinolates and other active components present in the canola plant which may have protective properties against tumor formation.

Glucosinolates from cruciferous vegetables are known for their ability to induce phase II detoxification enzyme system. One such enzyme is the GST detoxification enzyme which offers cellular protection by catalyzing the conjugation of carcinogenic electrophiles in the presence of glutathione, promoting the detoxification of carcinogens [42] [43]. The vegetables used in this study showed marked detoxification activity compared to the control. The lower tumor incidence seen in rats fed canola greens may be due to the ability of this cruciferous vegetable to stimulate their GST enzyme, thereby influencing detoxification of xenobiotics.

The antioxidant activity of the selected cruciferous vegetables provides some insight regarding the results seen in our treatment groups when compared to the control. Rats fed turnip greens had significantly $(\mathrm{P} \leq 0.05)$ higher levels of GSH compared to those fed the cabbage diet, however not significantly $(\mathrm{P} \leq 0.05)$ different from the rats fed collard greens and canola greens. The protective role of glutathione in cancer therapy is important because of the antioxidant's ability to conjugate and detoxify carcinogens [44] [45]. Sulforaphane and other precursors of glucosinolates, act not only in the detoxification of carcinogens, but also in inducing anti-oxidative cellular potential, while inhibiting angiogenesis [38]. Scientific data have reported an increase in antioxidant activities as a result of the presence of phenolic compounds which exert their chemoprotective properties by targeting or disrupting crucial events that are involved in cancer development [46]. The presence of bioactive compounds such as phenethylisothiocyanates (PEITC), benzyl isothiocyanates (BITC) and sulforaphanes in cruciferous vegetables may inhibit tumor initiation and promotion and decrease carcinogen activation [47].

\section{Conclusion}

The beneficial role of food compounds in effecting optimal health in humans cannot be overstated. Cruciferous vegetables have attracted much attention and, therefore, studied extensively because of their naturally occurring compounds which play a critical role in inhibiting neoplastic effects of carcinogens, thus reducing the risk of cancers in various organs. The detoxification and antioxidant potential of the vegetables used in this study were noticeable, not only in the traditional vegetables investigated but also in canola 
leafy greens. The results from this experiment indicate that cruciferous vegetables including canola greens may be effective in the inhibition of colon carcinogenesis which are consistent with epidemiological studies [8] [48] on cruciferous vegetables and their role in carcinogenesis. The hypothesized mechanism of action involves the modulation of biotransformation enzyme activities by glucosinolate hydrolysis products, and also their ability to act as suppressing agents during the promotion stage of the neoplastic process [36] [49].

\section{References}

[1] Knoops, K., de Groot, L., Kromhout, D., Perrin, A., Moreiras-Varela, O., Menotti, A. and van Staveren, W. (2004) Mediterranean Diet, Lifestyle Factors, and 10-Year Mortality in Elderly European Men and Women. JAMA, 292, 1433-1439.

http://dx.doi.org/10.1001/jama.292.12.1433

[2] Duilio, D., Tommaso, S.D., Salvemini, S., Garramone, M. and Crisci, R. (2006) Diet and Cancer. Acta Biomed, 77, 118-123.

[3] ACS, American Cancer Society (2011) Facts Figures and Statistics.

[4] Borek, C. (2004) Dietary Antioxidants and Human Cancer. Integrative Cancer Therapies, 3, 333-341. http://dx.doi.org/10.1177/1534735404270578

[5] Fimognari, C. and Hrelia, P. (2006) Sulforaphane as a Promising Molecule for Fighting Cancer. Mutation Research/Reviews in Mutation Research, 635, 90-104. http://dx.doi.org/10.1016/j.mrrev.2006.10.004

[6] Murillo, G. and Mehta, R.G. (2001) Cruciferous Vegetables and Cancer Prevention. Nutrition and Cancer, 1-2, 17-28. http://dx.doi.org/10.1080/01635581.2001.9680607

[7] Nho, C.W. and Jeffery, E. (2001) The Synergistic Upregulation of Phase II Detoxification Enzymes by Glucosinolate Breakdown Products in Cruciferous Vegetables. Toxicology and Applied Pharmacology, 174, 146-152. http://dx.doi.org/10.1006/taap.2001.9207

[8] Higdon, J.V., Delage, B., Williams, D. and Dashwood, R. (2007) Cruciferous Vegetables and Human Cancer Risk: Epidemiological Evidence and Mechanistic Basis. Pharmacological Research, The Official Journal of the Italian Pharmacological Society, 55, 224-236. http://dx.doi.org/10.1016/j.phrs.2007.01.009

[9] Miller-Cebert, R.L., Sistani, N.A. and Cebert, E. (2009) Comparative Mineral Composition among Canola Cultivars and Other Cruciferous Vegetables. Journal of Food Composition and Analysis, 22, 112-116. http://dx.doi.org/10.1016/j.jfca.2008.11.002

[10] Reeves, P.G., Nielsen, F.H. and Fahey, G.C. (1993) AIN-93 Purified Diets for Laboratory Rodents: Final Report of the American Institute of Nutrition Ad Hoc Writing Committee on the Reformulation of the AIN-76A Rodent Diet. Journal of Nutrition, 123, 1939-1951.

[11] Reeves, P.G., Rossow, K.L. and Lindlauf, J. (1993) Development and Testing of the AIN-93 Purified Diets for Rodents: Results on Growth, Kidney Calcification and Bone Mineralization in Rats and Mice. Journal of Nutrition, 123, 1923-1931.

[12] Shackelford, L.A., Rao, D.R., Chawan, C.B. and Pulusani, S.R. (1983) Effects of Feeding Fermented Milk on the Incidence of Chemically Induced Colon Tumors in Rats. Nutrition and Cancer, 5, 159-164. http://dx.doi.org/10.1080/01635588309513793

[13] Johansson, L.H. and Borg, L.A. (1988) A Spectrophotometric Method for Determination of Catalase Activity in Small Tissue Samples. Analytical Biochemistry, 174, 331.

http://dx.doi.org/10.1016/0003-2697(88)90554-4 
[14] Gajula, D., Verghese, M., Boateng, J., Shackelford, L. and Mentreddy, S.R. (2010) Basil (Ocimum basilicum and Ocimum tenui orum) Reduces Azoxymethane Induced Colon Tumors in Fisher 344 Male Rats. Research Journal of Phytochemistry, 4, 136-145. http://dx.doi.org/10.3923/rjphyto.2010.136.145

[15] Sengottuvelan, M. and Nalini, N. (2006) Dietary Supplementation of Resveratrol Suppresses Colonic Tumour Incidence in 1, 2-Dimethylhydrazine-Treated Rats by Modulating Biotransforming Enzymes and Aberrant Crypt Foci Development. British Journal of Nutrition, 96, 145-153. http://dx.doi.org/10.1079/BJN20061789

[16] Aggarwal, B.B. and Ichikawa, H. (2005) Molecular Targets and Anticancer Potential of Indole-3-Carbinol and Its Derivatives. Cell Cycle, 4, 1201-1215. http://dx.doi.org/10.4161/cc.4.9.1993

[17] Keck, A. and Finley, J.W. (2004) Cruciferous Vegetables: Cancer Protective Mechanisms of Glucosinolate Hydrolysis Products and Selenium. Integrative Cancer Therapies, 3, 5-12. http://dx.doi.org/10.1177/1534735403261831

[18] Zhang, Y. and Talalay, P. (1994) Anticarcinogenic Activities of Organic Isothiocyanates: Chemistry and Mechanisms. Cancer Research, 54, 1976s-1981s.

[19] Lee, P., Weerasuriya, D.K., Lavori, P.W., Quon, A., Hara, W., Maxim, P.G., Graves, E.E., et al. (2007) Metabolic Tumor Burden Predicts for Disease Progression and Death in Lung Cancer. International Journal of Radiation Oncology Biology Physics, 69, 328-333. http://dx.doi.org/10.1016/j.ijrobp.2007.04.036

[20] Shils, M.E., Shike, M., Ross, A.C., Caballero, B. and Cousins, R.J. (2005) Modern Nutrition in Health and Disease. Lippincott Williams \& Wilkins, Philadelphia.

[21] Roediger, W.E. (1980) Role of Anaerobic Bacteria in the Metabolic Welfare of the Colonic Mucosa in Man. Gut, 21, 793-798. http://dx.doi.org/10.1136/gut.21.9.793

[22] Wong, S.P., Leong, L.P. and William-Koh, J.H. (2006) Antioxidant Activities of Aqueous Extracts of Selected Plants. Food Chemistry, 99, 775-783. http://dx.doi.org/10.1016/j.foodchem.2005.07.058

[23] Wattenberg, L.W. (1992) Inhibition of Carcinogenesis by Minor Dietary Constituents. Cancer Research, 52, 2085s-2091s.

[24] Boffa, L.C., Lupton, J.R., Mariani., M.R., Ceppi, M., Newmark, H.L., Scalmati, A. and Lipkin, M. (1992) Modulation of Colonic Epithelial Cell Proliferation, Histone Acetylation, and Luminal Short Chain Fatty Acids by Variation of Dietary Fiber (Wheat Bran) in Rats. Cancer Research, 52, 5906-5912.

[25] Sakata, T. (1986) Effects of Indigestible Dietary bulk And Short Chain Fatty Acids on the Tissue Weight and Epithelial Cell Proliferation Rate of the Digestive Tract in Rats. Journal of Nutritional Science and Vitaminology, 32, 355-362. http://dx.doi.org/10.3177/jnsv.32.355

[26] Campbell, J.M., Fahey, G.C. and Wolf, B.W. (1997) Selected Indigestible Oligosaccharides Affect Large Bowel Mass, Cecal and Fecal Short-Chain Fatty Acids, pH and Microflora in Rats. The Journal of Nutrition, 127, 130-136.

[27] Kanauchi, O., Matsumoto, Y., Matsumura, M., Fukuoka, M. and Bamba, T. (2005) The Beneficial Effects of Microflora, Especially Obligate Anaerobes, and Their Products on the Colonic Environment in Inflammatory Bowel Disease. Current Pharmaceutical Design, 11, 1047-1053. http://dx.doi.org/10.2174/1381612053381675

[28] Topping, D.K. and Clifton, P.M. (2001) Short-Chain Fatty Acids and Human Colonic Function: Roles of Resistant Starch and Nonstarch Polysaccharides. Physiological Reviews, 81, 1031-1064.

[29] Pryde, S.E., Duncan, S.H., Hold, G.L. Stewart, C.S. and Flint, H.J. (2002) The Microbiology 
of Butyrate Formation in the Human Colon. FEMS Microbiology Letters, 27, 133-139. http://dx.doi.org/10.1111/j.1574-6968.2002.tb11467.x

[30] Wong, J.M.W., de Souza, R., Kendall, C.W.C., Emam, A. and Jenkins, D.J. (2006) Colonic Health: Fermentation and Short Chain Fatty Acids. Journal of Clinical Gastroenterology, 40, 235-243. http://dx.doi.org/10.1097/00004836-200603000-00015

[31] Chiao, J.W., Wu, H., Ramaswamy, G., Conaway, C.C., Chung, F., Wang, L. and Liu, D. (2004) Ingestion of an Isothiocyanate Metabolite from Cruciferous Vegetables Inhibits Growth of Human Prostate Cancer Cell Xenografts by Apoptosis And Cell Cycle Arrest. Carcinogenesis, 25, 1403-1408. http://dx.doi.org/10.1093/carcin/bgh136

[32] Eberhard, A., Kahlert, S., Goede, V., Hemmerlein, H., Plate, K.H. and Augustin, H.G. (2000) Heterogeneity of Angiogenesis and Blood Vessel Maturation in Human Tumors: Implications for Antiangiogenic Tumor Therapies. Cancer Research, 60, 1388-1393.

[33] Stan, S.D., Kar, S., Stoner, G.D. and Singh, S.V. (2008) Bioactive Food Components and Cancer Risk Reduction. Journal of Cellular Biochemistry, 104, 339-356. http://dx.doi.org/10.1002/jcb.21623

[34] Greten, F.R., Eckmann, L., Greten, F.T., Park, J.M., Zhi-Weie, J., Ega, L.J., Kagnoff, M.F. and Kari, M. (2004) IKK $\beta$ Links Inflammation and Tumorigenesis in a Mouse Model of Colitis-Associated Cancer. Cell, 118, 285-296. http://dx.doi.org/10.1016/j.cell.2004.07.013

[35] Mumm, J.B. and Oft, M. (2008) Cytokine-Based Transformation of Immune Surveillance into Tumor-Promoting Inflammation. Cytokine-Based Transformation of Immune Surveillance. Oncogene, 27, 5913-5919. http://dx.doi.org/10.1038/onc.2008.275

[36] Lampe, J.W. and Peterson, S. (2002) Brassica, Biotransformation and Cancer Risk: Genetic Polymorphisms Alter the Preventive Effects of Cruciferous Vegetables. The Journal of Nutrition, 132, 2991-2994.

[37] Heber, D. (2004) Vegetables, Fruits and Phytoestrogens in the Prevention of Diseases. Journal of Postgraduate Medicine, 50, 145-149.

[38] Herr, I. and Buckler, M.W. (2010) Dietary Constituents of Broccoli and Other Cruciferous Vegetables: Implications for Prevention and Therapy of Cancer. Cancer Treatment Reviews, 36, 377-383. http://dx.doi.org/10.1016/j.ctrv.2010.01.002

[39] Surh, Y.J. (2008) NF- $\kappa$ B and Nrf2 as Potential Chemopreventive Targets of Some AntiInflammatory and Antioxidative Phytonutrients with Anti-Inflammatory and Antioxidative Activities. Asia Pacific Journal of Clinical Nutrition, 17, 269-272. http://dx.doi.org/10.1016/j.ctrv.2010.01.002

[40] Surh, Y.J. and Na, H.K. (2008) NF- $\kappa$ B and Nrf2 as Prime Molecular Targets for Chemoprevention and Cytoprotection with Anti-Inflammatory and Antioxidant Phytochemicals. Genes and Nutrition, 2, 313-317. http://dx.doi.org/10.1007/s12263-007-0063-0

[41] Barrett, J.E., Klopfenstein, C.F. and Leipold, H.W. (1998) Protective Effects of Cruciferous Seed Meals and Hulls against Colon Cancer in Mice. Cancer Letters, 127, 83-88. http://dx.doi.org/10.1016/S0304-3835(98)00024-X

[42] Staack, R., Kingston, S., Wallig, M.A. and Jeffery, E.H. (1998) A Comparison of the Individual and Collective Effects of Four Glucosinolate Breakdown Products from Brussels Sprouts on Induction of Detoxification Enzymes. Toxicology and Applied Pharmacology, 149, 17-23. http://dx.doi.org/10.1006/taap.1997.8340

[43] Stoehlmacher, J., Park, D.J., Zhang, W., Groshen, S., Tsao-Wei, D.D., Yu, M.C. and Lenz, H. (2002) Association between Glutathione S-Transferase P1, T1, and M1 Genetic Polymorphism and Survival of Patients with Metastatic Colorectal Cancer. Journal of National Cancer Institute, 94, 936-942. http://dx.doi.org/10.1093/jnci/94.12.936 
[44] Balendiran, G.K., Dabur, R. and Fraser, D. (2004) The Role of Glutathione in Cancer. Cell Biochemistry and Function, 22, 343-352. http://dx.doi.org/10.1002/cbf.1149

[45] Podsedek, A. (2007) Natural Antioxidants and Antioxidant Capacity of Brassica Vegetables: A Review. LWT-Food Science and Technology, 40, 1-11. http://dx.doi.org/10.1016/j.lwt.2005.07.023

[46] Boivin, D., Lamy, S., Lord-Dufour, S., Jackson, J., Beaulieu, E., Côté, M., Moghrabi, A., Barrette, S., Gingras, D. and Béliveau, R. (2009) Antiproliferative and Antioxidant Activities of Common Vegetables: A Comparative Study. Food Chemistry, 112, 374-380. http://dx.doi.org/10.1016/j.foodchem.2008.05.084

[47] Tseng, S.H., Lin, S.W., Chen, J.C., Su, Y.H., Huang, H.Y., Chen, C.K., Lin, P.Y. and Chen, Y. (2004) Resveratrol Suppresses the Angiogenesis and Tumor Growth of Gliomas in Rats. Clinical Cancer Research, 10, 2190-2202. http://dx.doi.org/10.1158/1078-0432.CCR-03-0105

[48] Talalay, P. and Fahey, J.W. (2001) Phytochemicals from Cruciferous Plants Protect against Cancer by Modulating Carcinogen Metabolism. Journal of Nutrition, 131, 3027S-3033S.

[49] Verhoeven, D.T., Verhagen, H., Goldbohm, R.A., van den Brandt, P.A. and van Poppel, G. (1997) A Review of Mechanisms Underlying Anticarcinogenicity by Brassica Vegetables. Chemico-Biological Interactions, 103, 79-129. http://dx.doi.org/10.1016/S0009-2797(96)03745-3

Submit or recommend next manuscript to SCIRP and we will provide best service for you:

Accepting pre-submission inquiries through Email, Facebook, LinkedIn, Twitter, etc. A wide selection of journals (inclusive of 9 subjects, more than 200 journals)

Providing 24-hour high-quality service User-friendly online submission system

Fair and swift peer-review system Efficient typesetting and proofreading procedure

Display of the result of downloads and visits, as well as the number of cited articles Maximum dissemination of your research work

Submit your manuscript at: http://papersubmission.scirp.org/

Or contact fns@scirp.org 